\title{
Stage IV Renal Cell Cancer AJCC v8
}

National Cancer Institute

\section{Source}

National Cancer Institute. Stage IV Renal Cell Cancer AJCC v8. NCI Thesaurus. Code C140326.

Stage IV includes: (T4, Any N, M0); (Any T, Any N, M1). T4: T umor invading beyond Gerota's fascia (including contiguous extension into the ipsilateral adrenal gland). M0: No distant metastasis. M1: Distant metastasis. (AJCC 8th ed.) 